\title{
The Analysis of Legal Issues to the Houses With Limited Property Rights
}

\author{
Yilin Wang \\ College of Humanities and Social Sciences,North China Electric Power University, Beijing, 102206, \\ China
}

Keyword: Jurisprudence,The houses with limited property rights,Legal issues,Legal crises,Solution

\begin{abstract}
In recent years houses with limited property rights are inevitably becoming a topic that ignites controversy on a number of fronts. What is the limited property rights for houses?How shall we give a proper definition for them? Why are they so prosperous and what is the authority's stance?Whether they are legal or not? What legal crises could they cause?And why it's difficult to deal with?So many questions are urgent to be solved. And in this paper,I will explain the questions of all the above all.
\end{abstract}

\section{Introduction}

Houses with limited property rights are buildings which are constructed by developers or collective organizations on rural land. People who are not the members in collective organizations could not possess the certificate of house property. Therefore this kind of structure was called small property rights house compared with the full property rights house.

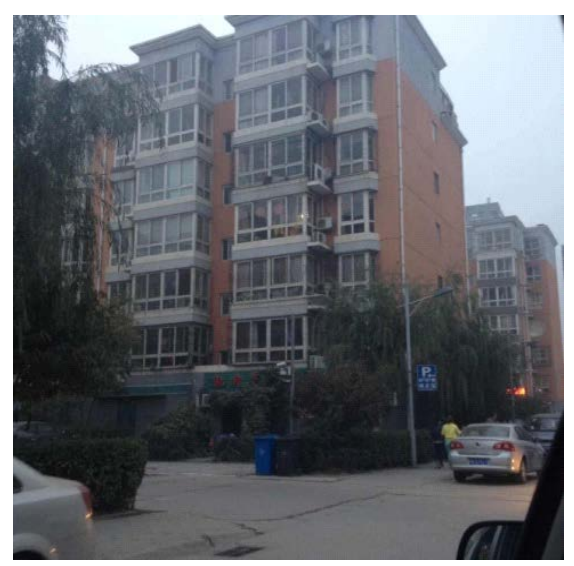

Fig. 1 Limited property rights houses in a housing estate in Changping, Beijing

According to the statistics,the area of the limited property rights houses has exceeded 0.76 billion square meters in our country from 1995 to 2010, more than 8 percent of the completed residential area during that same period. On the basis of the list published by Beijing authority which contained 85 construction programs being built up in 2013.And in 2014,housing volumes totaled 18.6 billion square meters in China. The ratio of the limited property rights houses was $33 \%$.

\section{The Legal Provision of the Houses With Limited Property Rights}

Even if the huge scale of the limited property rights houses, they lack a legitimate status. There are some examples stipulated in China's laws and regulations. 
The Law of Land Administration of the People's Republic of China Article 2. "The People's Republic of China resorts to a socialist public ownership i.e. an ownership by the whole people and ownership by collectives of land."

The Law of Land Administration of the People's Republic of China Article 63. "The land use right of peasant collectives shall not be leased, transferred or rented for non-agricultural construction."

The Law of the People's Republic of China on Urban Real Estate Administration Article 8. "The land users shall pay the States fees (the land-transferring fees) for using the land.

Not only these laws but also some government regulations put a ban on the construction and transaction of the houses with limited property rights. "

An emergency notice issued by Beijing State Land Bureau and Beijing Supervision Bureau in Feb.,2013. "To resolutely eliminate new constructions, strictly investigate and prosecute all those continued constructions."

The houses with limited property rights occupy the land owned by collectives for building buildings or non-agricultural construction, they also evade the land-transferring fees and are being sold to people who are not the members of collective organizations, which lead to their illegality. In spite of sever punishment by China's government, their momentum of development is formidable. Why are they so prosperous?

\section{The Root of the Houses With Limited Property Rights}

Abnormal development in real estate market. The increasing house price continues to be high in large Chinese cities in recent years. Let me give you some examples to illustrate this point. As shown in the figure,until April,2016,the house price in West District was the highest, which reached the number of 70,943 yuan per square meter. The next was East District, which was 62,384 yuan per square meter. And Haidian ranked third with a price of 56,836 yuan. The house price in other districts in Beijing were costly as well. The average price in the first half of 2016 was 30,834.29 yuan. Nevertheless, the per capital disposable income was only 28,488 at the same time. If a citizen would like to buy a house with 100 square meters, he would pay 30,834.29 $\times 100=3083,429$ yuan, excluding loan interests. And he need $3083,429 \div(28,488 \times 2) \approx 54$ years to repay his debt. By contrasts, the price of the houses with limited property rights were only 40-50 percent of the commodity houses' price simultaneously, in each district in Beijing.

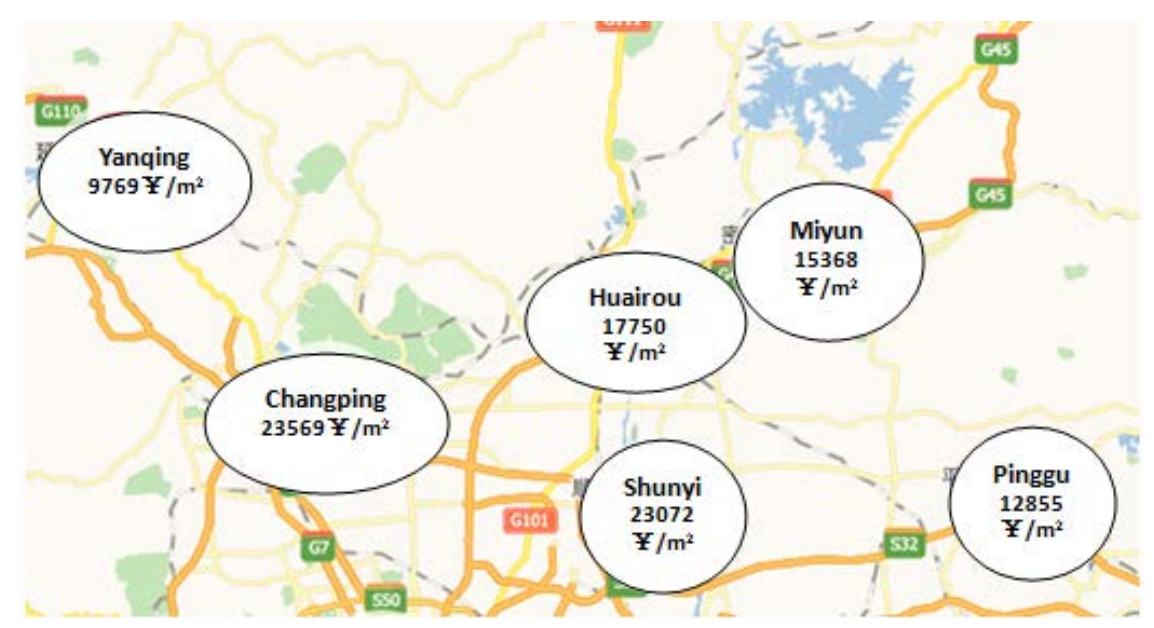

Fig. 2 The house price of some districts in Beijing in the first half of 2016 
As an estimate it reveals that the house price in large cities such as Beijing, Guangzhou and Shanghai is too high to accept. When it's becoming a kind of burden for people whose income is far below the house price. Making them choose those low-cost house such as the limited property rights house, instead of the commodity house.

Exorbitant land-transferring fees and taxes. Referring to the following tabulation for fiduciary price of land in Changping District in Beijing,2016.As an example, the land-transferring fee in Huilongguan area was achieved at 3,637 yuan per square meter. According to the relevant regulation about the land-transferring fee, if someone wants to construct buildings, he need to pay 60 percent of the fiduciary price as the land-transferring fee. So we can imagine that a house within 100 square meters has to pay 218,220 yuan as the land-transferring fee $(3,637 \times 60 \% \times 100=$ 218,220).Either the land-transferring fee or other relevant taxes are amazing.[2]

Table 1 Tabulation for Fiduciary Price of Land in Changping District,Beijing,2016

\begin{tabular}{|c|c|c|c|}
\hline \multicolumn{4}{|c|}{$\begin{array}{c}\text { Tabulation for Fiducial Price of Land in Changping } \\
\text { District,Beijing,2016 }\end{array}$} \\
\hline District & Typical Area & $\begin{array}{l}\text { Fiducial Price of } \\
\text { Land }\left(\nsucc / \mathrm{m}^{2}\right)\end{array}$ & Land Level \\
\hline \multirow{7}{*}{ Changping } & $\begin{array}{l}\text { South and North } \\
\text { Area }\end{array}$ & 2953 & More than 6 \\
\hline & Huilongguan Area & 3637 & More than 6 \\
\hline & Dongxiaokou Area & 3525 & More than 6 \\
\hline & North Qijia Area & 3301 & More than 6 \\
\hline & Shahe Area & 3170 & More than 6 \\
\hline & Baishan Area & 2937 & More than 6 \\
\hline & Xiaotangshan Area & 3104 & More than 6 \\
\hline
\end{tabular}

Because of evading a variety of fees and taxes, the price of houses with limited property rights was considerably below commodity houses. Which not only appeals to developers to invest but also attracts citizens to rush to purchase.

Fuzzy or deficient in relevant laws and regulations. Whereas the laws have regulated that bargains between the limited property rights houses were forbidden, they failed to deal with the problem essentially. Legal provision in The Law of Land Administration of the People's Republic of China said that, the rural residential land belongs to collectives, villagers only have the rights of use. It can not be protected by laws if villagers sell the houses built on rural residential land to citizen. However there is no legislation to define whether it is legal or not to lease these houses which are built on rural land. In the name of leasing, some people actually bargain those houses.[1]

Functions between government departments cross and overlap. On the other hand, government departments, such as the construction department, the planning department, the agriculture department and the department of land and resources, are also responsible for the problem. Since the functions between these departments cross and overlap seriously in China, the supervision is restricted. 


\section{The Legal Crises of the Houses with Limited Property Rights}

Building on rural residential land, evading fees and taxes, which leads to their illegality. Without certificates of land use right and pre-sale licenses, transactions between them are prohibited. Because of these reasons, people who purchased the houses have enormous risks. First of all, the house-purchaser don't have the rights to own, transfer, dispose and earn profits. Second, the houses are regarded as illegal buildings by government. The attitude of the authority is to implement restraint rigorously[3].On account of that, purchasers may not get compensation after land requisition or demolition. Third ,the houses are incapable of mortgaging, circulating and inheriting. Next, the contracts signed by contracting parties are illicit. So the property of purchasers would hardly be safeguarded when disputes occur to them. Last but not least, the quality of these houses are unsecured for the lack of supervision from government.

\section{The Difficulty of the Houses With Limited Property Rights}

Forced demolition may be chosen to eliminate the houses. While the profits involved in these houses are extensive. A mass riot would be triggered by the forced demolition. Furthermore, after stern demolishing, people who lost their homes must be perplexed just because the houses are what we need to live by. On the contrary, if we give recognition of these houses, it's also unfair to those people who spent much more money to buy the commodity houses. And it will be more rampant to invest and build the limited property rights houses. We are indeed caught in a dilemma, so all of those conundrums are urgent to solve.

\section{Conclusion}

The limited property rights houses become pervasive during these years for many reasons. In spite of their short of the legitimate status and much higher risks, there are a great many of people who are willing to hazard all these risks and eager to buy the limited property rights houses. The gross area has already achieved a great number. As we can Imagine, the huge size of these houses means that Chinese government is facing an arduous challenge.

\section{References}

[1]W. Ge\&Y.S. Liu. The Research of Legal Issues and Solutions to the House With Limited Property Rights[D](In Chinese). Southwest University of Political Science and Law. 2013.

[2]H. Liu\&H.Y. Liu. The Research of legal Issues to the Limited Property Rights[D](In Chinese).Changchun University of Science and Technology.2013.

[3]F.F. Si\&J.H. Du. The Research of Civil Legal problems of the Small Property House[D](In Chinese).Liaoning University.2012. 